\title{
Mass Selection of Conditional Mating Mutants of Tetrahymena thermophila
}

\author{
By JASON WOLFE \\ Biology Department, Wesleyan University, Middletown, Connecticut 06457, U.S.A.
}

(Received 27 February 1979; revised 3 May 1979)

\begin{abstract}
The mating reaction in Tetrahymena thermophila includes a starvation period and two distinct cell interactions, co-stimulation and cell pairing, before the cells are cytoplasmically joined as conjugants. A selection procedure for harvesting mutants unable to mate at a restrictive temperature has been developed. A conjugant pair consisting of one cycloheximide-resistant cell and one wild-type cell (cycloheximide-sensitive) was itself sensitive to the drug. By adding cycloheximide and nutrient medium to a cross made at the restrictive temperature, only cycloheximide-resistant cells that did not successfully conjugate could survive and grow. Repetition of the selection procedure enriched for cells unable to conjugate at the restrictive temperature. The selected cells were able to grow at $38^{\circ} \mathrm{C}$ and could conjugate at $28^{\circ} \mathrm{C}$. This procedure may be narrowed to select specifically for cell interaction mutants.
\end{abstract}

\section{INTRODUCTION}

The developmental sequence leading to the establishment of conjugant pairs between Tetrahymena cells of complementary mating types begins with a period of starvation of at least $2 \mathrm{~h}$ during which the cells become competent to engage in intercellular mating interactions (Wolfe, 1973; Bruns \& Brussard, 1974b). This period is followed sequentially by (i) a $1 \mathrm{~h}$ co-stimulation interaction which involves specific contacts between the cells (Bruns \& Palestine, 1975) resulting in a morphological transformation of their anterior tips (Wolfe \& Grimes, 1979), (ii) a pairing interaction resulting in the attachment of complementary cells at their modified tips (Wolfe \& Grimes, 1979), and (iii) fusion of the paired cells' plasma membranes in several localized foci within the region of cell attachment (Wolfe \& Loyter, 1975).

It would be useful to have a procedure that specifically selected for lesions in the preconjugation process, especially mutants of the cell interactions, to assist in understanding the mechanisms by which these interactions take place. Temperature-sensitive mutants would be extremely valuable since genetic analysis of cells that cannot mate is otherwise difficult or impossible and temperature shifts can be useful for biochemical analyses.

Between mutagenesis and selection a cross is essential. The phenotype of a cell results from expression of genes in the polyploid macronucleus. During conjugation, gamete pronuclei derived meiotically from the micronuclei of the two participating cells fuse to form a zygote nucleus, which in both cells develops into new micro- and macronuclei. Thus, by crossing the cells, mutations in the quiescent micronucleus are transferred into a new macronucleus where they may be expressed. After several divisions phenotypic assortment (Sonneborn, 1974) takes place. Then, a given cell expresses either of two alleles for a particular gene, a condition which remains stable for all further generations. This being the case, recessive mutations are expressed in the macronucleus of about half of the cells. This procedure allows for direct selection of recessive traits (Carlson, 1971). 
To select for conditional mating mutants one must be able to separate cells that cannot mate from cells that can. The problem is exacerbated by the fact that in a normal cross 10 to $30 \%$ of the cells do not mate. Thus one must also be able to separate cells that cannot mate from cells that do not mate.

Our strategy was to use a drug-resistant mutant as one of the mating types. We show that successful conjugation involving one drug-resistant cell and one drug-sensitive cell is itself sensitive. When the drug is applied, such conjugant pairs do not survive. The non-conjugating individuals of the sensitive mating type also die. The survivors are the sexually mature drug-resistant cells that either could not or did not mate. By subjecting these cells to repeated mating challenges with the sensitive strain eventually all but the cells that cannot mate at the restrictive temperature are eliminated.

\section{METHODS}

Mating types III and VII of subline B of Tetrahymena thermophila [previously known as syngen 1 of $T$. pyriformis (Nanney \& McCoy, 1976)] were cultured separately in nutrient medium $(2 \%, \mathrm{w} / \mathrm{v}$, proteose peptone) at $28{ }^{\circ} \mathrm{C}$ without agitation or aeration. Preparations for mating were initiated by transferring cells, under sterile conditions, from nutrient medium to a sterile non-nutrient buffer $\left(10 \mathrm{mM}\right.$-Tris pH $7 \cdot 4 ; 10^{5}$ cells $\mathrm{ml}^{-1}$ ). Cells were starved for $18 \mathrm{~h}$ before mixing. Mating was induced by mixing equal volumes of BIII and BVII cells and incubating them at $28^{\circ} \mathrm{C}$ in an Erlenmeyer flask whose capacity was at least 10 times the volume of the incubation mixture. Cells were fixed, counted in a haemocytometer and scored for pairing as described previously (Adair et al., 1978).

Mutagenesis was done on cells in nutrient medium at a density of 20000 to 50000 cells ml-1 by incubation for $3 \mathrm{~h}$ with $N$-methyl- $N^{\prime}$-nitro- $N$-nitrosoguanidine (MNNG; $10 \mu \mathrm{g} \mathrm{ml}^{-1}$; Aldrich Chemical Co., Milwaukee, Wis., U.S.A.). The cells were then washed three times with proteose peptone to remove the mutagen and allowed to recover for $3 \mathrm{~h}$ before transferring them to buffer in preparation for mating.

Cells were returned to proteose peptone at a convenient time between 6 and $24 \mathrm{~h}$ after crossing and subcultured three times per week for 2 weeks. At this point all cells were of a single mating type, BIII. We have shown (B. Barel \& J. Wolfe, unpublished results) that this was due to differential growth of the two mating types by cultivating equal inocula together in nutrient medium for 2 weeks, using the same triweekly subcultivation routine: there was a gradual and complete reduction in the number of BVII cells present.

Cloning of cells in 96-well microtitre plates was performed as described by Orias \& Bruns (1976). Cell suspension was diluted to 1 cell $\mathrm{ml}^{-1}$ and $0 \cdot 2 \mathrm{ml}$ was distributed to each well with a microdrop apparatus (Cooke Laboratory Products, Alexandria, Va., U.S.A.).

Cycloheximide-resistant cells were selected as follows. Both mating types were subjected to mutagenesis, crossed and subcultured for 2 weeks. Cell suspension $\left(1 \mathrm{ml}, 10^{5}\right.$ cells ml-1) was then introduced into each of 20 culture tubes containing $9 \mathrm{ml}$ medium plus $25 \mu \mathrm{g}$ cycloheximide $\mathrm{ml}^{-1}$. As a control, 20 tubes were similarly inoculated with normal BIII. None of the control tubes showed growth, while 11 of the 20 cultures derived from cells treated with MNNG contained growing cells which were therefore resistant to cycloheximide. One tube was selected, cultured in proteose peptone, and on retesting with cycloheximide showed continued resistance. These cells were backcrossed to wild-type BVII, subcultured and cloned. Fifty-four clones were established: 21 were cycloheximide-resistant, of which eight grew well and were labelled Chx-1 to Chx-8. The clone which showed the best growth in cycloheximide, Chx-4, was chosen for use in the selection of temperature-sensitive cells for mating.

\section{RESULTS \\ Effect of cycloheximide on single cells}

To examine the growth of individual cells in the presence of cycloheximide, one wild-type BIII strain and two cycloheximide-resistant BIII strains (Chx-3, Chx-4) were incubated for 1 week in microtitre plates containing proteose peptone with or without cycloheximide (Table 1). All three strains plated without cycloheximide grew as expected (i.e. in approximately 200 wells of the 10 plates used). No wild-type cells grew in plates containing cycloheximide (at 10 or $25 \mu \mathrm{g} \mathrm{ml}-1$ ). With strain Chx-3 and $10 \mu \mathrm{g}$ cycloheximide $\mathrm{ml}^{-1}$ the number of wells with cell growth was reduced while Chx-4 was unaffected. At $25 \mu \mathrm{g}$ cycloheximide $\mathrm{ml}^{-1}$ only about $25 \%$ of Chx-3 and $50 \%$ of Chx-4 cells survived and grew. Clearly 
Table 1. Response of several BIII strains to cycloheximide

Cultures of one wild-type BIII strain and two cycloheximide-resistant BIII strains (Chx-3 and Chx-4) were diluted to 1 cell $\mathrm{ml}^{-1}$ and distributed in 10 microtitre plates, each with 96 wells. Each well received $0.2 \mathrm{ml}$ proteose peptone with or without cycloheximide. Plates were incubated for 1 week and then the numbers of wells showing growth were counted.

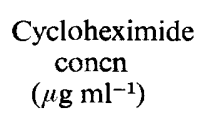

0

10

25

\begin{tabular}{ccc}
\multicolumn{3}{c}{ No. of wells showing growth } \\
\hline $\begin{array}{c}\text { Strain } \\
\text { BIII }\end{array}$ & Strain & Strain \\
188 & Chx-3 & Chx-4 \\
0 & 206 & 182 \\
0 & 146 & 182 \\
& 40 & 92
\end{tabular}

some cells of the cycloheximide-resistant strains were sensitive to cycloheximide. Thus, a cycloheximide concentration of $10 \mu \mathrm{g} \mathrm{ml}^{-1}$ completely inhibited growth of wild-type cells while permitting complete growth of $\mathrm{Chx}-4$ cells.

\section{Effect of cycloheximide on conjugant pairs}

To determine whether a conjugant pair consisting of one wild-type cell and one cycloheximide-resistant cell was sensitive or resistant to cycloheximide, a cross was made between equal numbers of Chx-4 BIII cells and wild-type BVII cells. At $6 \mathrm{~h}$ after mixing, 90\% of the cells had paired. At this point the cells were returned to proteose peptone, diluted to 1 cell ml $\mathrm{ml}^{-1}$ and divided into two groups, one with $10 \mu \mathrm{g}$ cycloheximide $\mathrm{ml}^{-1}$ and the other without cycloheximide. Each group was plated at 1 unit (cell or pair) $\mathrm{ml}^{-1}$ into 10 microtitre plates and incubated at $28{ }^{\circ} \mathrm{C}$ for 1 week. The plates were then scored for the number of wells in which cells had grown.

Since $90 \%$ of the cells had paired, and the cells were plated at 1 unit (single or pair) $\mathrm{ml}^{-1}$, in 45 of every 55 wells $(81.8 \%)$ that received a unit, that unit should be a pair. Of the remaining wells, half $(9 \cdot 1 \%)$ should consist of single resistant cells and half $(9 \cdot 1 \%)$ should be single sensitive cells. If all pairs were cycloheximide-resistant then growth in plates containing cycloheximide would be about $90 \%$ of that in control plates. Alternatively, if the pairs were sensitive then growth would be about $10 \%$ of that of the controls. In fact, $15.4 \%$ growth occurred in the cycloheximide group indicating that a conjugant pair of mixed phenotypes was sensitive to cycloheximide.

To verify this, another cross was made between Chx-4 and wild-type cells, and $6 \mathrm{~h}$ after mixing the cells were returned to proteose peptone containing $10 \mu \mathrm{g}$ cycloheximide $\mathrm{ml}^{-1}$ and incubated for $3 \mathrm{~d}$. The resistant cells grew but the sensitive cells died. Examination of the cells by phase contrast microscopy revealed the presence of dead conjugant pairs. Thus a mixed conjugant pair consisting of cycloheximide-resistant and cycloheximide-sensitive partners was itself cycloheximide-sensitive.

\section{Selection of temperature-sensitive non-maters}

The ability to selectively kill conjugant pairs while saving a parental type that did not pair formed the basis for the mass selection of variants unable to mate at a restrictive temperature. Chx-4 cells were treated with $\mathrm{MNNG}$, crossed and then subcultured for 2 weeks to (i) transfer mutations into the macronucleus, (ii) permit phenotypic assortment and (iii) generate, through differential growth rates, a population consisting solely of mating type BIII. Cycloheximide-resistant cells were selected from the culture to provide the starting material for the selection of temperature-sensitive mating mutants. To be as inclusive as possible, cells were incubated at $38^{\circ} \mathrm{C}$ from the time of transfer to buffer until they were returned to proteose peptone $6 \mathrm{~h}$ after mixing with wild-type BVII. Cycloheximide was 


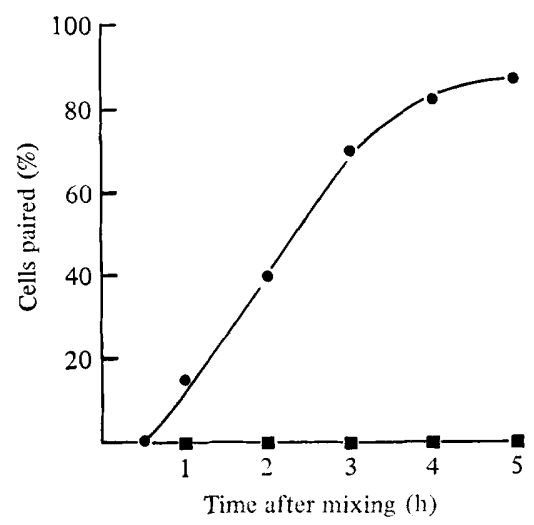

Fig. 1. Kinetics of pairing of Tetrahymena thermophila. Cells mass-selected by the recycling procedure (see Results) were mixed with wild-type BVII and pairing was measured at $28^{\circ} \mathrm{C}(\mathbf{O})$ and $38^{\circ} \mathrm{C}(\square)$. There was no pairing at $38^{\circ} \mathrm{C}$ even after $24 \mathrm{~h}$.

added and the cells were then incubated at $28^{\circ} \mathrm{C}$ for $2 \mathrm{~d}$ before repeating the cycle. The cycle was repeated four times; there was no pairing in the fourth cycle.

The non-maters at $38^{\circ} \mathrm{C}$ were then grown and subcultured at $38^{\circ} \mathrm{C}$ for 1 week to eliminate those cells that simply disfunctioned at the elevated temperature. A subsequent conjugation test done at $28{ }^{\circ} \mathrm{C}$ showed normal kinetics of pairing (Fig. 1). Thus the selected population consisted of cells able to grow at 28 and $38^{\circ} \mathrm{C}$, able to mate at $28^{\circ} \mathrm{C}$, but not able to pair when starved and maintained at $38^{\circ} \mathrm{C}$.

Over 120 clones were established. Each was tested separately and the expected temperature-related mating properties were confirmed. Furthermore, cells of each clone showed normal pairing if starved at $28{ }^{\circ} \mathrm{C}$ but crossed at $38^{\circ} \mathrm{C}$. Therefore, for each clone selected the lesion occurred during the initial starvation period, or initiation.

\section{DISCUSSION}

We have outlined a successful strategy for the selection of mutants of Tetrahymena thermophila unable to mate at a restrictive temperature but able to mate at a normal temperature. This is the first time that mass selection of mating mutants has been achieved for any ciliate. Temperature-sensitive mutants blocked in cytokinesis have been collected (Frankel et al., 1976), and a general procedure for the selection of temperature-sensitive mutants has recently been outlined for Tetrahymena (Bruns \& Sanford, 1978). The potential utility of Tetrahymena as a cell type for genetic analysis has increased dramatically with the exploitation of phenotypic assortment (Sonneborn, 1974) to produce functional heterokaryons (Bruns \& Brussard, 1974a), genomic exclusion (Allen, 1967) to yield homozygotes in a matter of hours (Bruns et al., 1976), and the microtitre technology for mass testing of clones (Orias \& Bruns, 1976). The availability of a procedure for selection of mating mutants should be of value in coupling genetic and biochemical analyses to the sequence of events surrounding the development of the sexual pathway.

In this initial selection attempt, we set conditions to be all-inclusive so that lesions during starvation, co-stimulation or pairing could, in theory, be collected. In fact, all of the variants had lesions in the starvation period, the time during which the cells become competent to engage in the co-stimulation interaction. These strains should be valuable in analysing specific events during starvation which are causally related to the development of mating competency.

We have previously argued that the development of mating competency involves a change at the cell surface which renders the cell competent to participate in the co-stimulation 
interaction (Adair \& Wolfe, 1977). More recently, we have shown that an extracellular factor is required for cell interactions during co-stimulation (Adair et al., 1978). Some of the temperature-sensitive mating variants selected here might be blocked either at the level of the surface change or in the ability to utilize the factor.

Furthermore, it is conceivable that some of the selected variants that are unable to become competent at $38{ }^{\circ} \mathrm{C}$ are cell cycle mutants. Conjugation in Tetrahymena takes place exclusively in the G1 phase of the cell cycle (Wolfe, 1973; Doerder \& DeBault, 1975), specifically in the A segment of G1 (Wolfe, 1976). Cells in the G1B, S or G2 phases at the time of nutrient shift-down can eventually divide during starvation, thus arriving at $\mathrm{G} 1$, in which condition they can conjugate. Cells blocked in any of the stages of the cell cycle other than G1A by the high temperature and starvation conditions will not traverse the cell cycle and should be unable to pair. Thus, this selection strategy could provide an indirect means of obtaining mutants with a temperature-sensitive modification of their ability to traverse the cell cycle. This discussion pertains only to traverse under starvation conditions; under nutrient conditions, as demonstrated, growth is not blocked by the higher temperature.

The success of the selection strategy described hinges on the fact that a conjugant pair consisting of one cycloheximide-resistant member and one cycloheximide-sensitive member is itself cycloheximide-sensitive. Thus, successful conjugants are killed. Whether this phenomenon is of a general nature or applies only to the particular cycloheximide-resistant mutant used in this study is now under investigation. It must also be stressed that our observation on the sensitivity of the mixed conjugant pair is entirely empirical and is not easy to explain theoretically. Approximately $1 \mathrm{~h}$ after cells have paired, they establish cytoplasmic continuity through limited regions of membrane fusion in the special cell junction formed at the attachment area (Wolfe \& Loyter, 1975). McDonald (1966) has shown by autoradiography that when one cell is labelled with $\left[{ }^{3} \mathrm{H}\right]$ leucine or $\left[{ }^{3} \mathrm{H}\right]$ uridine some ${ }^{3} \mathrm{H}$ is later found in the conjugant partner. Conceivably proteins and even ribosomes can pass from one cell to the other. It might therefore be expected that if resistance is at the level of the ribosome, a conjugant pair with one cycloheximide-resistant member would be resistant. Perhaps, however, cytoplasmic flow through the channels is limited. Electron microscopic examination of the channels indicates the presence of whorls of filamentous material, while ribosomes and other cytoplasmic particles seem excluded from this area (unpublished results). Perhaps, even if cytoplasmic flow is not limited, the burden of one cell supporting two under starvation conditions is too great. Also, it is possible that resistance to cycloheximide here is at the level of the cell surface, in which case a conjugant pair would most definitely be sensitive.

The selection scheme can be narrowed to yield potentially more interesting cell interaction mutants by simply applying the restrictive temperature after competency has been achieved, i.e. after starvation but before mixing the two mating types. The later that one applies the restrictive temperature, the later in the developmental sequence one selects for. We thus anticipate the selection of co-stimulation mutants, cell pairing or adhesion mutants, and even membrane fusion mutants.

It should be noted that a mutant of one mating type that is unable to mate with a second mating type under restrictive conditions may still be able to mate with a third mating type. The basis of mating type specificity in Tetrahymena is still unclear; perhaps mating mutants will help in sorting out this problem.

Note added in proof. To test for fertility, cells of each variant were crossed to a functional heterokaryon, strain SB210. This strain, obtained from Dr E. Orias, carries a gene for resistance to deoxygalactose. If the progeny from a cross between a mating variant and SB210 survived in $2.5 \mathrm{mg}$ deoxygalactose $\mathrm{ml}^{-1}$, the variant was scored as fertile. By this criterion, greater than $80 \%$ of the isolated variants were fertile. 
I am indebted to Ms Jan Oles for her dedicated effort in developing the tools and methods necessary to conduct these experiments. This work was supported by NIH grant GM 18014. J.W. is a recipient of a NIH career development award.

\section{REFERENCES}

ADAIR, W. S. \& Wolfe, J. (1977). Induced alteration in uptake properties of Tetrahymena and its association with the development of mating competency. Journal of Cell Physiology 92, 77-90.

ADAIR, W. S., BARKer, R., TURNER, R. S., JR \& WOLFE, J. (1978). Demonstration of a cell-free factor involved in cell interactions during mating in Tetrahymena. Nature, London 274, 54-55.

Allen, S. L. (1967). Genomic exclusion: a rapid means of inducing homozygous diploid lines in Tetrahymena pyriformis syngen 1. Science 155, 575-577.

Bruns, P. J. \& Brussard, T. B. (1974a). Positive selection for mating with functional heterokaryons in Tetrahymena pyriformis. Genetics 78, 831-841.

Bruns, P. J. \& Brussard, T. B. (1974b). Pair formation in Tetrahymena pyriformis, an inducible developmental system. Journal of Experimental Zoology 188, 337-344.

Bruns, P. J. \& Palestine, R. F. (1975). Costimulation in Tetrahymena pyriformis: a developmental interaction between specially prepared cells. Developmental Biology 42, 75-83.

Bruns, P. J. \& SANFord, Y. M. (1978). Mass isolation and fertility testing of temperature sensitive mutants in Tetrahymena. Proceedings of the National Academy of Sciences of the United States of America 75, 3355-3358.

Bruns, P. J., Brussard, T. B. \& Kavka, A. B. (1976). Isolation of homozygous mutants after induced self-fertilization in Tetrahymena. Proceedings of the National Academy of Sciences of the United States of America 73, 3243-3247.

Carlson, P. S. (1971). Mutant selection in Tetrahymena pyriformis. Genetics 69, 261-265.

Doerder, F. F. \& DeBault, L. E. (1975). Cyto- fluorimetric analysis of nuclear DNA during meiosis, fertilization and macronuclear development in the ciliate Tetrahymena pyriformis, syngen 1. Journal of Cell Science 17, 471-493.

Frankel, J., Jenkins, L. M., Doerder, F. P. \& NeLSEN, E. M. (1976). Mutations affecting cell division in Tetrahymena pyriformis. I. Selection and genetic analysis. Genetics 83, 337-344.

MCDonald, B. B. (1966). The exchange of RNA and protein during conjugation in Tetrahymena. Journal of Protozoology 13, 277-285.

NANNEY, D. L. \& MCCOY, J. W. (1976). Characterization of the species of the Tetrahymena pyriformis complex. Transactions of the American Microscopical Society 95, 664-682.

OrIAS, E. \& BRUNS, P. J. (1976). Induction and isolation of mutants in Tetrahymena. Methods in Cell Biology 13, 247-282.

SONNEBORN, T. (1974). Tetrahymena pyriformis. In Hundbook of Genetics, vol. 2, pp. 433-467. Edited by $R$. C. King. New York: Plenum.

Wolfe, J. (1973). Conjugation in Tetrahymena: the relationship between the division cycle and cell pairing. Developmental Biology 35, 221-231.

WOLFE, J. (1976). G1 arrest and the division/conjugation decision in Tetrahymena. Developmental Biology 54, 116-126.

WolfE, J. \& Grimes, G. W. (1979). Tip transformation in Tetrahymena: a morphogenetic response to interactions between mating types. Journal of Protozoology (in the Press).

Wolfe, J. \& Loyter, A. (1975). Plasma membrane fusion and pore formation in conjugating Tetrahymena: freeze-etch study. Journal of Cell Biology 67, 459 (abstract). 